\title{
Effects of no-tillage systems on soil physical properties and carbon sequestration under long-term wheat-maize double cropping system
}

\author{
Manxiang Huang, Tao Liang *, Lingqing Wang *, Chenghu Zhou \\ Key Laboratory of Land Surface Pattern and Simulation, Institute of Geographical Sciences and Natural Resources Research, Chinese Academy of Sciences, Beijing 100101, China
}

\section{A R T I C L E I N F O}

\section{Article history:}

Received 28 March 2014

Received in revised form 28 January 2015

Accepted 2 February 2015

Available online 18 February 2015

\section{Keywords:}

No tillage system

Conventional tillage system

Soil physical properties

Carbon sequestration

Crop residue

Manure

Wheat-maize double cropping

\begin{abstract}
A B S T R A C T
A thorough assessment of changes in soil quality associated with soil management practices is vital for the selection and establishment of sustainable agricultural management. The winter wheat (Triticum aestivum L.)-maize (Zea mays L.) double cropping system was used to study the integrated effects of a 9-year-old tillage coupled with fertilization on soil carbon sequestration and other physical properties in the Yellow River Delta (YRD). Three tillage systems were selected: no-tillage with straw cover plus recommended urea nitrogen rate (NTS), no-tillage with straw removed and manure applied plus recommended urea nitrogen rate (NTM), and conventional tillage with straw removed plus conventional urea nitrogen application rate (CT). There were three replicates of each treatment organized in a randomized block design. NTS and NTM treatments were found to result in a slightly decrease in the soil bulk density (BD), and significantly increased the proportion of water stable aggregates (WSA) (>2 mm), as well as the water infiltration capacity. The proportion of water stable macroaggregates $(>0.25 \mathrm{~mm})$, the mean weight diameter (MWD) and the geometric mean diameter (GMD) of aggregates in the 0-20 cm layer were unchanged by NTS and NTM. The total soil organic carbon (SOC) stock at a depth of 0-60 cm was not significantly different among the treatments. Both aggregate-associated SOC concentration and stocks (0-5 cm) were significantly greater for NTS and NTM compared with CT, while CT led to a greater OC accumulation in the 20-60 cm soil layer compared with NTS and in the 10-20 cm compared with NTM. The mesoaggregate fraction $(2-0.25 \mathrm{~mm}$ ) and its associated $\mathrm{OC}$ pool accounted for the highest percentages in the whole soil profile under the CT treatment. The NT system was found to have a positive effect on the investigated soil physical properties and increase soil carbon content in the soil surface layer. The CT system in conjunction with the wheat-maize double cropping system, however, improved soil aggregation in the soil profile $(0-60 \mathrm{~cm})$ and also maintained a higher fraction of SOC in the subsoil compared with the NT systems.
\end{abstract}

(c) 2015 Elsevier B.V. All rights reserved.

\section{Introduction}

Soil organic matter (SOM) and various physical properties are important indicators of soil quality and play an important role in the soil functionality of production (Shukla et al., 2006; Benbi and Chand, 2007). Cavalieri et al. (2009) reported that dynamic properties such as soil aeration, aggregation, bulk density and water transmission have a greater impact on soil physical quality in the surface layers. Soil organic carbon (SOC) is the measured major determining factor of soil physical properties. SOC sequestration is related to the agricultural contribution of soil to $\mathrm{CO}_{2}$ emissions and subsequent effect on global climate change (Buyanovsky and Wagner, 1998; Lal, 2004).

Soil aggregates are closely correlated with both soil physical properties and SOC sequestration. SOM is known to compress mineral particles into aggregates to improve soil structure and stability (Tisdall and Oades, 1982; Tejada et al., 2006). Soils with good structural generally display a high water-holding capacity, moderate saturated hydraulic

\footnotetext{
* Corresponding authors.

E-mail addresses: liangt@igsnrr.ac.cn (T. Liang), wanglq@igsnrr.ac.cn (L. Wang).
}

conductivity, and sufficient aeration for plant establishment and growth (Jastrow and Miller, 1991; Karami et al., 2012). In addition, stable aggregates may better protect SOM from decomposition (Six et al., 1999; Haile et al., 2008; Abiven et al., 2009; Carter, 2004). Soil aggregate fractionation has been widely used to evaluate the SOC stability and the impacts of soil management on SOC dynamics (Six et al., 2002; Kou et al., 2012).

Soil physical properties and soil gaseous emissions are influenced by agricultural practices such as tillage, cropping systems, and fertilization (Yang et al., 2008; Obalum and Obi, 2010). Intense tillage can increase surface soil compaction, reduce aggregate stability, disrupt surface vented pores, decrease retention and transmission of water and solutes, and exacerbate losses due to runoff and erosion. Intense tillage may also deplete SOM as a result of the increased rate of organic carbon mineralization following tillage as well as contribute to erosion loss and reduced cycling of organic matter through crop removal (Gregorich et al., 2001; Yu et al., 2006). Soils under no tillage (NT) management systems tend to become more porous with time due to the creation of a more stable soil structure, an increase in the SOM pool and an increase in the number of biopores directly connected to the soil surface. Higher 
infiltration rate measured in NT compared with conventional tillage (CT) may be attributed to macropore flow and reduced surface sealing under the mulch (Goddard et al., 2008). However, previous studies have also shown adverse conclusions about physical properties and SOC sequestration under NT (Wright et al., 2005; Pastorelli et al., 2013). Such findings necessitate an improved understanding of the impacts of NT systems on soil C sequestration and SOC stability.

Long-term unbalanced inorganic fertilizer application alone has been shown to negatively impact crop yields and also reduce the benefits of fertilization. While balanced fertilization of chemical fertilizers may be capable of sustaining current crop yields, such practice is likely to induce soil acidification and degradation of soil structure in a long term (Huang et al., 2010). Residue management and artificial addition of organic material sources, including the production and incorporation of green manure crops, application of livestock manure, and crop residue incorporation into the topsoil, are among the more promising methods for improving soil structural and aggregation properties (Bhattacharyya et al., 2009; Wagner et al., 2007). Long-term application of organic matters has been found to increase SOC and soil microbial activity, and in turn produce positive effects on mean weight diameter (MWD) and geometric mean diameter (GMD), while simultaneously decrease bulk density (BD) and increase infiltration rates (Fliebbach et al., 2007; Karami et al., 2012). The use of organic fertilizers and compost has also found to enhance the SOC sequestration to a greater extent compared with application of equivalent amount of inorganic fertilizers (Gregorich et al., 2001). Pathak et al. (2011) reported that the application of $\mathrm{N}, \mathrm{P}$ and $\mathrm{K}$ in combination with farmyard manure sequestered a higher fraction of SOC compared with the control.

Although the separate effects of tillage, cropping systems, and fertilizer on soil physical quality and SOC sequestration have been previously documented, there is limited information available regarding the combined effects of these practices. Wang and Dala (2006) evaluated the combined effects of NT, stubble retention (SR) and N fertilization (NF) on SOC sequestration. When NT, SR, or NF was applied alone, no significant effect on SOC was measured in the 0-10 cm layer. However,maximum SOC sequestration was achieved under a combined $\mathrm{NT}+\mathrm{SR}+\mathrm{NF}$ treatment, suggesting that the long-term sustainability of corn production under manure application can be mainly attributed to the improved soil quality. In order to promote soil C sequestration and sustainable agricultural production, reduced tillage systems should be developed in conjunction with judicious organic management (Guo and Zhou, 2007; Pathak et al., 2011). Although no-tillage and other conservation tillage practices have the potential to increase the SOC pool by increasing residue and manure inputs and decreasing $C$ loss, these practices may also increase $\mathrm{N}_{2} \mathrm{O}$ emission and nitrate leaching (Mkhabela et al., 2008). There is a need for research related to the capacity of $\mathrm{N}$ in straw and manure as a crop nutrient to reduce the use of mineral $\mathrm{N}$ fertilizer under NT (Robertson et al., 2000; Pastorelli et al., 2013).

The Yellow River Delta (YRD) is an important agronomic and animal husbandry area in the North China Plain. According to the soil survey data (1979-1983) and the FAO-Uneso system, the soil is classified as a calcaric fluvisol (referred locally to as Chao soil). The Chao soil originates from the alluvial parent material of the YRD and was named for its historically salty characteristics. The salinity problems in this region have been alleviated through the development of an extensive irrigation-drainage system. At present, these practices are representative of the middle to high yield agricultural productivity of a winter wheat-summer maize double crop under a conventional tillage system. Over the past few decades, the adoption of NT practices has increased due to reduced costs and the lower amount of fieldwork required relative to conventional tillage. Approximately $23 \%$ of the total YRD area is currently under NT system (Dai et al., 2009). Several studies have evaluated the effect of tillage and fertilizer management regimes on crop yields and the environment (Huang et al., 2015). Generally, the practice of organic matter (crop straw or manure) inputs with a reduced urea rate under NT has been found to have no significant impact on crop yields compared with CT, while the treatment of crop straw rather than manure application with a reduced urea rate under NT significantly decreased $\mathrm{N}_{2} \mathrm{O}$ emissions and $\mathrm{NO}_{3}-\mathrm{N}$ leaching loss in YRD. However, the feasibility of NT in YRD depends if the quality of a soil being conversed from CT to NT with organic material inputs is improving, remaining stable or declining in the YRD (Lal, 1998; Shukla et al., 2006). There is limited information available regarding the combined effects of NT with organic fertilizer plus mineral fertilizer application on soil quality in this region.

The objective of this study was to investigate the influence of three different tillage systems (NT with straw cover plus recommended urea nitrogen rate (NTS), NT with straw removed and manure applied plus recommended urea nitrogen rate (NTM), and conventional tillage with straw removed plus convention $\mathrm{N}$ rate $(\mathrm{CT})$ ) on soil physical properties. The hypotheses tested were as follows: compared to CT, (1) NTS and NTM will decrease soil density and increase soil water infiltration than CT; and (2) the practice of organic matter inputs together with a reduced urea rate under no-till will significantly increase SOC under the winter wheat/maize double cropping system in the YRD.

\section{Materials and methods}

\subsection{Location of the experimental site}

Experiments beginning in 2003 were designed to investigate the long-term effects of different farming practices on soil properties and crop yields in Beiqiu, the YRD, China. Long-term average annual rainfall in this area is approximately $600 \mathrm{~mm}$ with a rainy season from July to September and a mean annual temperature of $13.5{ }^{\circ} \mathrm{C}$. The annual total reference evapotranspiration is $879.3 \mathrm{~mm}$ and the aridity index is approximately 0.68 . The surface soil texture is silty loam (sand, $12 \%$; silt, $66 \%$; clay, $22 \%$ ) according to the USDA classification system. Additional soil features are listed in Table 1.

\subsection{Treatments used}

The experiment was organized in a randomized complete block design with the three treatments (NTS, NTM, and CT). There were three replicates for each treatment. The plot size was $300 \mathrm{~m}^{2}(7.5 \mathrm{~m}$ width $\times 40 \mathrm{~m}$ length). Two crops, winter wheat (Jimei 22) and summer maize (Dehai 7), were grown annually. Winter wheat was seeded $(\mathrm{NHH}$ 2BXF-9 planter with width of $1570 \mathrm{~mm}$ ) between 10 and 15 October, and harvested (4LZ-5120 combine harvester with width of $2500 \mathrm{~mm}$ ) during the first $10 \mathrm{~d}$ of June. Summer maize was then seeded (2BYSF3 maize seeder with width of $1420 \mathrm{~mm}$ ) between 15 and 25 October. After harvesting (4YZP-2 maize harvester with width of $1660 \mathrm{~mm}$ ), the standing stubble of each crop was cut to the same height (15 to $20 \mathrm{~cm}$ for wheat and $10 \mathrm{~cm}$ for maize), and all other residues were removed for NTM and CT.

For the CT treatment, a moldboard plow was used with a tillage depth of ca. $25 \mathrm{~cm}$ followed by disk harrowing to fully incorporate standing stubble into the soil after the maize harvest. As is historically

Table 1

General soil characteristics for the surface soil $(20 \mathrm{~cm})$ at the experimental site.

\begin{tabular}{ll}
\hline $\mathrm{pH}\left(\mathrm{H}_{2} \mathrm{O}, 1: 2.5\right)$ & $8.3(0.1)$ \\
$\mathrm{EC} 1,5\left(\mathrm{dS} \mathrm{m}^{-1}\right)$ & $0.12(0.0)$ \\
$\mathrm{CaCO} 3(\%)$ & $6.8(1.1)$ \\
Total $\mathrm{N}\left(\mathrm{g} \mathrm{kg}^{-1}\right)$ & $0.76(0.05)$ \\
Olsen $\mathrm{P}\left(\mathrm{mg} \mathrm{kg}^{-1}\right)$ & $16.8(3.4)$ \\
$\mathrm{CEC}\left(\mathrm{cmol} \mathrm{kg}^{-1}\right)$ & $12.0(2.5)$ \\
Water retention $\left(\mathrm{kg} \mathrm{kg}^{-1}\right)$ & \\
$33 \mathrm{kPa}$ & 0.16 \\
$1500 \mathrm{kPa}$ & 0.05 \\
\hline
\end{tabular}

Numbers in parentheses are standard errors. 
common in the YRD, there was no tillage before maize seeding under CT.

After harvesting crops under NTS treatment, crop residues were shredded into pieces (approximately $5 \mathrm{~cm}$ in length) by hand and plots were covered by residue at fixed rates of $5.92 \mathrm{Mg} \mathrm{ha}^{-1}$ for wheat straw (N content of $7.60 \mathrm{~g} / \mathrm{kg}, \mathrm{C}: \mathrm{N}$ ca. 60:1) during maize planting and $4.93 \mathrm{Mg} \mathrm{ha}^{-1}$ for maize straw ( $\mathrm{N}$ content of $9.12 \mathrm{~g} / \mathrm{kg}$, C:N ca. 42:1) during wheat planting.

During the NTM treatment, dry cattle (Bos taurus) manure at a rate of $1.73 \mathrm{Mg} \mathrm{ha}^{-1}$ was applied by hand and left on the surface before winter wheat and maize seeding. Manure $\mathrm{N}, \mathrm{P}_{2} \mathrm{O}_{5}, \mathrm{~K}_{2} \mathrm{O}$ and $\mathrm{C}$ contents were $26.0,10.5,16.7$ and $450 \mathrm{~g} / \mathrm{kg}$, respectively.

An equivalent total $\mathrm{N}$ application rate of $225 \mathrm{~kg} \mathrm{~N} \mathrm{ha}^{-1}$ for each crop was used under each of the three treatments. The $\mathrm{N}$ application rate for each crop as mineral fertilizer under the NTS, NTM, and CT systems was $180 \mathrm{~kg} \mathrm{~N} \mathrm{ha}{ }^{-1}$, with an additional $45 \mathrm{~kg} \mathrm{~N} \mathrm{ha}^{-1}$ applied as mineral fertilizer under CT, as dry manure under NTM and as crop straw under NTS. The chemical nitrogen fertilizer rate of $225 \mathrm{~kg} \mathrm{~N} \mathrm{ha}^{-1}$ for each crop is a conventional fertilization rate in the north China plain, while $180 \mathrm{~kg} \mathrm{~N} \mathrm{ha}^{-1}$ is the current recommended application (Huang et al., 2011; Liu et al., 2003).

Under CT treatment, urea for winter wheat was used with $45 \mathrm{~kg} \mathrm{~N} \mathrm{ha}^{-1}$ as the base fertilizer and the remaining fraction was used as supplementary fertilizer in equal proportions in late March (wheat green turn stage) and mid-April (wheat stem elongation stage) in the following year. For summer maize, urea $\left(225 \mathrm{~kg} \mathrm{~N} \mathrm{ha}^{-1}\right)$ was applied during the early growth period. Base fertilizer for winter wheat was incorporated with a moldboard plowing operation into the top $25 \mathrm{~cm}$ of soil.

Under both the NTS and NTM systems, urea (180 $\left.\mathrm{kg} \mathrm{N} \mathrm{ha}^{-1}\right)$ for winter wheat was surface applied in equal quantities in late March and mid-April, and in a single dose during the early growth period for maize. Maize straw ( $45 \mathrm{~kg} \mathrm{~N} \mathrm{ha}^{-1}$ ) for winter wheat and wheat straw (45 $\mathrm{kg} \mathrm{N} \mathrm{ha}^{-1}$ ) for summer maize were surface applied before planting under NTS. Manure ( $45 \mathrm{~kg} \mathrm{~N} \mathrm{ha}^{-1}$ ) for winter wheat and summer maize was applied to the soil surface before planting under NTM.

All other management procedures were identical for the three treatments. Herbicide (2,4-dichlorophenoxyacetic acid butylate) and insecticide (40\% dimethoate, 0,0-dimethyl S-[2-(methylamino)-2-oxoethyl] dithiophosphate) were applied after sowing of wheat in October and maize in June, respectively.

\subsection{Soil sampling and analysis}

Soil sampling was conducted in October 2012 after the maize harvest. Five representatives' field-moist soil samples were collected from each of the replicate treatment areas at depths of $0-5,5-10,10-20$, $20-40$ and $40-60 \mathrm{~cm}$ with a bucket auger. Aliquots were pooled together to create a composite sample for each depth and replicate. Once in the laboratory, field-moist soil was passed through a 4.75-mm sieve and then air-dried and stored at room temperature. Additional triplicate undisturbed soil cores ( $5.0 \mathrm{~cm}$ diameter and $8.0 \mathrm{~cm}$ length) collected using a stainless steel core sampler were used for the determination of BD for the same five depths mentioned above following the method of Blake and Hartge (1986).

A wet sieving procedure was used for determination of the aggregate-size distribution and stability (Elliott and Cambardella, 1991). Approximately $100 \mathrm{~g}$ of air-dried ( $4.75 \mathrm{~mm}$ sieved) soil samples was capillary-wetted to field capacity to minimize slaking following immersion. Wetted soil was immersed in water on a nest of sieves $(2 \mathrm{~mm}$, $250 \mu \mathrm{m}$, and $53 \mu \mathrm{m}$ ) and shaken $3 \mathrm{~cm}$ vertically for 50 times over a 2min period. Soil fractions retained on each sieve along with a subsample taken from the soil suspension collected in the oscillation cylinder that passed through a $53 \mu \mathrm{m}$ sieve ('silt + clay' sized fraction) were transferred into a pre-weighted container and dried at $65^{\circ} \mathrm{C}$. The amount of material that passed through the $53-\mu \mathrm{m}$ sieve was determined from the difference between whole soil and the sum of the three aggregatesize fractions ( $>2 \mathrm{~mm}, 250 \mu \mathrm{m}-2 \mathrm{~mm}$, and 53-250 $\mu \mathrm{m}$ ). Using this method, different aggregate-size fractions including coarse macroaggregates (>2 mm), mesoaggregates ( $250 \mu \mathrm{m}-2 \mathrm{~mm})$, microaggregates (53-250 $\mu \mathrm{m})$, and a 'silt + clay' fraction $(<53 \mu \mathrm{m})$ were collected. Subsamples from each aggregate size fraction were then ground to pass a $0.5-\mathrm{mm}$ sieve and analyzed for SOC. Whole soil samples that were not used for aggregate size fractionation were also analyzed.

SOC was determined using a modified Mebius method (Nelson and Somers, 1982). Briefly, $0.5 \mathrm{~g}$ of soil was digested with $5 \mathrm{~mL}$ of $1.0 \mathrm{~N}$ $\mathrm{K}_{2} \mathrm{Cr}_{2} \mathrm{O}_{7}$ and $10 \mathrm{~mL}$ of $\mathrm{H}_{2} \mathrm{SO}_{4}$ at $150{ }^{\circ} \mathrm{C}$ for $30 \mathrm{~min}$, followed by titration of the digests with standardized $\mathrm{FeSO}_{4}$. Since sand-associated $\mathrm{C}$ was assumed to be minimal (Elliott and Cambardella, 1991), adjustments were made for sand contents in different aggregate size fractions.

After collecting sand for all aggregate fractions by dispersal in sodium hexametaphosphate, the water stable aggregates (WSA), MWD and GMD of the WSA were estimated following the methods of Oguike and Mbagwu (2009) and Karami et al. (2012). Aggregates were then divided into water-stable macroaggregate (WSMacA, $>0.25 \mathrm{~mm}$ ) and microaggregate (WSMicA, $<0.25 \mathrm{~mm}$ ) categories and their mass ratio was designated as aggregate ratio (AR).

The OC pool was calculated from OC concentration $\left(\mathrm{g} \mathrm{kg}^{-1}\right)$ for each soil depth to $\mathrm{Mg} \mathrm{ha}^{-1}$ using the following equation:

C-Pool $\left(\mathrm{Mgha}^{-1}\right)=\mathrm{A} \times \mathrm{D} \times \mathrm{Bd} \times \mathrm{OC} \times 10^{-3}$

where $A$ is the area (ha: $10^{4} \mathrm{~m}^{2}$ ); D is the depth (m); Bd is the bulk density $\left(\mathrm{Mg} \mathrm{m}^{-3}\right)$; and $\mathrm{OC}$ is the aggregate-associated organic carbon concentration $\left(\mathrm{g} \mathrm{kg}^{-1}\right)$ (Lal et al., 1998).

The cumulative values of organic $C$ present in soil aggregate size fractions of $>2.0 \mathrm{~mm}, 0.25-2.0 \mathrm{~mm}, 0.053-0.25 \mathrm{~mm}$ and $<0.053 \mathrm{~mm}$ were defined as coarse macroaggregated $\mathrm{C}$ (CMacAOC), mesoaggregated C (MesAOC), coarse microaggregated C (CMicAOC) and 'silt + clay'associated OC, respectively. The sum of organic $C$ in the $>0.25 \mathrm{~mm}$ aggregate size fractions was referred to as macroaggregated organic $\mathrm{C}$ (MacAOC), while organic $\mathrm{C}$ in the $<0.25 \mathrm{~mm}$ size fractions was dubbed microaggregated organic C (MicAOC).

\subsection{Water infiltration}

The infiltration rate in the experimental plots was measured in October 2012 after the harvest of maize crop using the double rings method, with a $50 \mathrm{~cm}$ outer diameter and $30 \mathrm{~cm}$ inner diameter. Measurements were conducted over $180 \mathrm{~min}$. The data were fit to the Philip's (1957) model for soil water sorptivity (S) and transmissivity (A) using the following numerical analysis:

$\mathrm{I}=\mathrm{St}^{1 / 2}+\mathrm{At}, \quad \mathrm{i}=0.5 \mathrm{St}^{-(1 / 2)}+\mathrm{A}$

where I is the cumulative infiltration ( $\mathrm{mm}), \mathrm{i}$ is the infiltration rate ( $\mathrm{min}), \mathrm{t}$ is the time $(\mathrm{min}), \mathrm{S}$ is the soil water sorptivity $\left(\mathrm{mm} \mathrm{min}^{-0.5}\right)$, $A$ is the transmissivity (mm) equal to $\mathrm{I} / \mathrm{T}^{1 / 2}$, and $\mathrm{T}$ is the cumulative time.

\subsection{Statistical analysis}

The independent variables in the study included $\mathrm{Bd}$, aggregate size fraction, AR, MWD, GMD, SOC concentration, SOC stock, S, A, I, $\mathrm{i}_{\mathrm{c}}$ and $\mathrm{i}_{\mathrm{i}}$. Differences among treatments were evaluated using single-factor analysis of variances (ANOVA). Multiple comparisons of means were conducted with a Fisher's protected least significant difference (LSD) test $(\mathrm{P}<0.05)$. 
Table 2

Effect of combined tillage and fertilization on soil infiltration characteristics after 9 years of wheat-maize crop double rotation $(0-20 \mathrm{~cm})$.

\begin{tabular}{|c|c|c|c|c|c|c|}
\hline \multirow[t]{2}{*}{ Treatments } & $\mathrm{Bd}$ & $S$ & A & $\mathrm{i}_{\mathrm{i}}$ & $\mathrm{i}_{\mathrm{c}}$ & I \\
\hline & $\overline{\mathrm{Mg} \mathrm{m}^{-3}}$ & $\overline{\mathrm{mm} \mathrm{min}^{-0.5}}$ & & $\mathrm{mmh}^{-1}$ & & $\mathrm{~mm}$ \\
\hline $\mathrm{CT}$ & 1.43 & 3.0 & $3.1 \mathrm{~b}$ & $26.0 \mathrm{~b}$ & $11.5 b$ & $48.0 \mathrm{~b}$ \\
\hline NTS & 1.37 & 3.6 & $10.5 a$ & $38.7 a$ & $21.3 a$ & $81.3 a$ \\
\hline NTM & 1.38 & 3.6 & $8.5 a$ & $36.3 a$ & 19.6a & $78.0 \mathrm{a}$ \\
\hline $\mathrm{LSD}_{0.05}$ & NS & NS & 4.3 & 6.2 & 3.1 & 11.6 \\
\hline
\end{tabular}

CT: conventional tillage; NTS: no-tillage with residue cover; NTM: no-tillage with residue removed and manure applied. NS: not significant. Bd: bulk density; S: sorptivity; A: transmissivity; $\mathrm{i}_{\mathrm{i}}$ : initial infiltration rate; $\mathrm{i}_{\mathrm{c}}$ : steady-state infiltration rate; I: mean cumulative infiltration in $3 \mathrm{~h}$.

\section{Results}

\subsection{Soil bulk density and water transmission properties}

No significant differences for BD across the soil profile between treatments were observed. At a depth of $0-20 \mathrm{~cm}$, NTS and NTM resulted in a decrease in the soil bulk density to a greater extent than CT, however, the difference was not statistically significant (Table 2). The bulk density of soils exposed to different treatments averaged 1.47 and $1.42 \mathrm{~g} \mathrm{~cm}^{-3}$ in the $20-40 \mathrm{~cm}$ and $40-60 \mathrm{~cm}$ depth layers, respectively. The initial infiltration rate $\left(i_{i}\right)$, steady state infiltration rate $\left(i_{c}\right)$ and cumulative infiltration (I) increased significantly in the NTS- and NTM-treated plots. Cumulative infiltration was observed to increase by up to $69.4 \%$ and $62.5 \%$ under NTS and NTM treatments, respectively, compared with CT treatment ( $48 \mathrm{~mm}$ in $3 \mathrm{~h}$ ), with equilibrium rates $84.9 \%$ and $69.8 \%$ higher compared with CT $\left(11.5 \mathrm{~mm} \mathrm{~h}^{-1}\right)$. NT produced no significant effect on soil sorptivity. The transmissivity (A) in NTS- and NTM-treated plots was determined to be $237 \%$ and $173 \%$ higher than that of the CT plots.

\subsection{SOC stock}

At depths of 0 to $60 \mathrm{~cm}$ in the soil, the total SOC concentrations ranged from 3.0 to $12.9 \mathrm{~g} \mathrm{~kg}^{-1}$ (Table 3 ). The SOC concentrations under NTS in the $0-10 \mathrm{~cm}$ soil layer and under NTM in the $0-5 \mathrm{~cm}$ layer were significantly greater compared with those under $\mathrm{CT}$. In the 5-10 cm soil layer, the SOC concentration under NTS was higher than under NTM. However, a higher concentration of SOC in the CT-treated plots was found at a depth of 40-60 cm compared with the NTS and NTM plots. The difference in SOC content for the different soil depths between CT and NTS and NTM was similar to the trend observed in the SOC concentration (Table 4). NTS produced a significantly higher SOC content in the $0-10 \mathrm{~cm}$ soil layer than the CT system and compared with NTM in the 5-10 cm soil layer. Higher SOC content was also found in the $0-5 \mathrm{~cm}$ soil layer of NTM plots compared with the CT system. In contrast, the $20-60 \mathrm{~cm}$ layer of the CT plots and the $20-40 \mathrm{~cm}$
Table 4

Soil organic carbon (SOC) distribution and content under different treatments in the Yellow River Delta (YRD).

\begin{tabular}{lcccc}
\hline \multirow{4}{*}{ Soil depth $(\mathrm{cm})$} & \multicolumn{2}{l}{ Soil organic carbon content } & & \\
\cline { 2 - 3 } & \multicolumn{2}{l}{$\mathrm{Mg} \mathrm{ha}^{-1}$} & & \\
\cline { 2 - 3 } & $\mathrm{CT}$ & $\mathrm{NTS}$ & SSD $_{0.05}$ \\
\hline $0-5$ & $5.4(0.3)^{\mathrm{a}}$ & $8.3(0.6)^{\mathrm{b}}$ & $7.4(1.0)$ & 0.9 \\
$5-10$ & $5.4(0.4)^{\mathrm{a}}$ & $7.8(0.8)$ & $5.6(0.8)$ & 1.3 \\
$10-20$ & $10.6(1.0)$ & $10.4(2.2)$ & $8.1(1.40)$ & 1.0 \\
$20-40$ & $16.0(0.2)^{\mathrm{a}}$ & $13.5(0.3)$ & $15.3(1.7)$ & 1.3 \\
$40-60$ & $10.9(0.3)^{\mathrm{a}}$ & $8.5(1.0)$ & $9.6(0.8)$ & 1.3 \\
$0-60$ & $48.5(4.4)$ & $48.4(5.9)$ & $45.3(4.5)$ & NS \\
\hline
\end{tabular}

CT, conventional tillage; NTS: no-tillage with residue cover; NTM: no-tillage with residue removed and manure applied.

a Within each depth values are significantly different between tillage systems at $\mathrm{P}<0.05$.

b Values in parentheses are the standard errors of the mean.

layer of NTM plots were found to contain significantly higher SOC compared with NTS plots. No difference in the total SOC content up to a depth of $60 \mathrm{~cm}$ was observed among the different treatments.

\subsection{Aggregate size distribution}

The distribution of soil aggregate fraction size classes in the soil profile was stratified, which was significantly different among the treatments (Table 5). The percentages of WSMacA $(>0.25 \mathrm{~mm})$ and AR for all treatments were higher in the $0-10 \mathrm{~cm}$ surface layer compared with those in the deeper soil. Except in the $0-5 \mathrm{~cm}$ soil layer, the CT system was found to significantly increase the percentage of soil aggregate $>0.25 \mathrm{~mm}$ and AR in the deeper soil layers compared with the NT system. While the percentage of aggregates $>2.0 \mathrm{~mm}$ in the $0-20 \mathrm{~cm}$ soil layer in plots treated with NTS and NTM was greater compared with $\mathrm{CT}$, the amounts of small macroaggregates $(0.25-2 \mathrm{~mm})$ in CT-treated plots were significantly greater compared with NTS and NTM at all soil depths. The percentages of coarse microaggregates in the 10$60 \mathrm{~cm}$ soil layers and silt + clay fractions in the $0-10$ and $40-60 \mathrm{~cm}$ soil layers in both NTS and NTM treatments were significantly higher compared to the CT treatment.

\subsection{Aggregate associated carbon concentration}

On average, the aggregate-associated OC concentration in the soil (Table 6) tended to decrease with increasing soil depth $(P<0.05)$ with the exception of coarse microaggregated $C$ in NTM-treated soil $(P=0.32)$. The distribution of SOC within aggregates was as follows: mesoaggregates $(0.25-2.0 \mathrm{~mm})>$ coarse microaggregates $(0.053-$ $0.25 \mathrm{~mm})>$ silt + clay $(<0.053 \mathrm{~mm})>$ coarse macroaggregates $(>2.0 \mathrm{~mm})$. Each fraction accounted for $55.2,22.7,16.7$ and $5.4 \%$ of the total aggregated $\mathrm{OC}$, respectively.

Table 3

Soil organic carbon (SOC) concentrations under different treatments in the Yellow River Delta (YRD).

\begin{tabular}{|c|c|c|c|c|}
\hline \multirow[b]{3}{*}{ Soil depth (cm) } & \multicolumn{3}{|c|}{ Soil organic carbon concentration } & \multirow[b]{3}{*}{$\mathrm{LSD}_{0.05}$} \\
\hline & \multicolumn{3}{|l|}{$\mathrm{g} \mathrm{kg}^{-1}$} & \\
\hline & $\mathrm{CT}$ & NTS & NTM & \\
\hline $0-5$ & $8.3(0.4)^{*}$ a 9 & 12.9 (1.0)\#а & $11.7(1.8) \mathrm{a}$ & 1.7 \\
\hline $5-10$ & $7.5(0.5) * a b$ & $10.2(1.1) b$ & $7.8 \mathrm{~b}(0.6) \mathrm{c}$ & 0.95 \\
\hline $10-20$ & $6.9(0.7) \mathrm{b}$ & $6.7(0.6) c$ & $5.6(0.3) \mathrm{cd}$ & NS \\
\hline $20-40$ & $5.4(0.3) \mathrm{c}$ & $4.5(0.7) d$ & $5.4(0.4) d$ & NS \\
\hline $40-60$ & $3.8(0.6)^{*} \mathrm{~d}$ & $3.0(0.1) \mathrm{e}$ & $3.1(0.2) \mathrm{e}$ & 0.62 \\
\hline
\end{tabular}

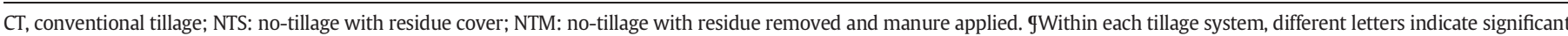

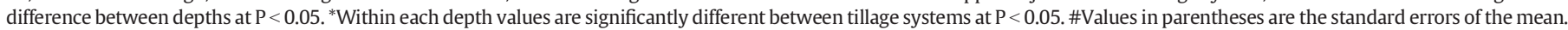


Table 5

Structural indices and distribution of particle size at soil depths under different treatments after 9 years of winter wheat-maize double cropping.

\begin{tabular}{|c|c|c|c|c|c|c|c|c|}
\hline \multirow[t]{2}{*}{ Treatments } & \multicolumn{5}{|c|}{ WSA (\%) } & \multirow[t]{2}{*}{ AR } & \multirow{2}{*}{$\frac{\mathrm{MWD}}{\mathrm{mm}}$} & \multirow[t]{2}{*}{ GMD } \\
\hline & $>2$ & $0.25-2$ & $0.25-0.05$ & $<0.05$ & $>0.25$ & & & \\
\hline \multicolumn{9}{|l|}{$0-0.05 \mathrm{~m}$} \\
\hline $\mathrm{CT}$ & $3.6 b^{1}$ & $62.8 \mathrm{a}$ & 18.1 & $15.5 \mathrm{~b}$ & $66.5 A^{2}$ & $2.0 \mathrm{~A}$ & 0.87 & 0.80 \\
\hline NTS & $11.5 \mathrm{a}$ & $50.6 \mathrm{~b}$ & 16.8 & $21.3 a$ & $62.1 \mathrm{~A}$ & $1.65 \mathrm{~A}$ & 1.01 & 0.89 \\
\hline NTM & $10.9 a$ & $50.9 \mathrm{~b}$ & 19.0 & $19.2 \mathrm{a}$ & $61.8 \mathrm{~A}$ & $1.64 \mathrm{~A}$ & 0.99 & 0.85 \\
\hline $\mathrm{LSD}_{0.05}$ & 2.8 & 4.8 & NS & 2.1 & NS & NS & NS & NS \\
\hline \multicolumn{9}{|l|}{$0.05-0.10 \mathrm{~m}$} \\
\hline $\mathrm{CT}$ & $5.3 b$ & $60.3 a$ & 18.2 & $14.7 \mathrm{~b}$ & $65.7 \mathrm{aA}$ & $2.2 \mathrm{aA}$ & 0.9 & 0.80 \\
\hline NTS & $8.0 \mathrm{a}$ & $49.7 b$ & 20.9 & $21.4 a$ & $57.7 \mathrm{bA}$ & $1.38 \mathrm{bA}$ & 0.88 & 0.79 \\
\hline NTM & $8.0 \mathrm{a}$ & $51.1 \mathrm{~b}$ & 21.8 & 19.1a & $59.1 \mathrm{bA}$ & $1.48 \mathrm{bA}$ & 0.89 & 0.78 \\
\hline $\mathrm{LSD}_{0.05}$ & 1.2 & 8.5 & NS & 3.3 & 4.1 & 1.8 & NS & NS \\
\hline \multicolumn{9}{|l|}{$0.10-0.20 \mathrm{~m}$} \\
\hline $\mathrm{CT}$ & $1.8 \mathrm{~b}$ & $48.4 a$ & $30.3 c$ & $19.5 b$ & $50.3 \mathrm{aC}$ & $1.01 \mathrm{aC}$ & 0.66 & 0.62 \\
\hline NTS & $6.1 \mathrm{a}$ & $39.1 b$ & $34.6 a$ & $19.9 b$ & $45.2 \mathrm{bB}$ & $0.89 \mathrm{bB}$ & 0.71 & 0.61 \\
\hline NTM & $5.4 a$ & $33.7 \mathrm{c}$ & $32.5 \mathrm{~b}$ & $28.4 a$ & $39.1 \mathrm{cC}$ & $0.65 \mathrm{cC}$ & 0.63 & 0.60 \\
\hline $\mathrm{LSD}_{0.05}$ & 1.2 & 2.4 & 1.8 & 5.2 & 5.1 & 0.1 & NS & NS \\
\hline \multicolumn{9}{|l|}{$0.20-0.40 \mathrm{~m}$} \\
\hline $\mathrm{CT}$ & 0.7 & $55.4 a$ & $23.3 b$ & $20.6 b$ & $56.1 \mathrm{aB}$ & $1.30 \mathrm{aB}$ & 0.69 & 0.69 \\
\hline NTS & 1.4 & $41.6 c$ & $29.2 \mathrm{a}$ & $27.9 a$ & $43.0 \mathrm{cB}$ & $0.77 \mathrm{bB}$ & 0.58 & 0.62 \\
\hline NTM & 1.7 & $47.4 \mathrm{~b}$ & $28.3 a$ & $22.2 \mathrm{~b}$ & 49.5bB & 0.98abB & 0.66 & 0.64 \\
\hline $\mathrm{LSD}_{0.05}$ & NS & 2.7 & 4.1 & 4.1 & 4.2 & 0.4 & NS & NS \\
\hline \multicolumn{9}{|l|}{$0.40-0.60 \mathrm{~m}$} \\
\hline $\mathrm{CT}$ & 0.8 & $58.9 a$ & $19.4 \mathrm{c}$ & $20.9 c$ & $59.7 \mathrm{aB}$ & $1.60 \mathrm{aB}$ & 0.73 & 0.76 \\
\hline NTS & 1.0 & $43.0 \mathrm{~b}$ & $28.8 b$ & $27.2 \mathrm{~b}$ & 44.0bB & $0.85 \mathrm{bB}$ & 0.58 & 0.62 \\
\hline NTM & 0.8 & $30.2 \mathrm{c}$ & $35.6 a$ & $33.4 a$ & $31.0 \mathrm{cD}$ & $0.48 \mathrm{bD}$ & 0.44 & 0.53 \\
\hline $\mathrm{LSD}_{0.05}$ & NS & 9.7 & 4.2 & 3.8 & 3.5 & 0.69 & NS & NS \\
\hline
\end{tabular}

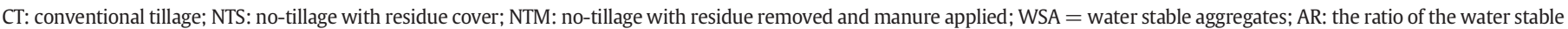
macroaggregate $(>0.25 \mathrm{~mm}$ ) and microaggregate $(<0.25 \mathrm{~mm})$; MWD: mean weight diameter; GMD: geometric mean diameter.

1 Within a column of an aggregated OC, numbers followed by different lowercase letters are significantly different between treatments at each depth at P $\leq 0.05$ by LSD test.

2 Within each tillage system, different letters indicate significant difference between depths at $\mathrm{P}<0.05$.

Table 6

Aggregate associated organic carbon concentration (AOC) in soil profile under different treatments after 9 years of winter wheat-maize double cropping.

\begin{tabular}{|c|c|c|c|c|}
\hline \multirow[t]{3}{*}{ Treatments } & \multicolumn{4}{|c|}{ Aggregate associated organic carbon (AOC) } \\
\hline & Coarse macroaggregate $(>2 \mathrm{~mm})$ & Mesoaggregate (0.25-2 mm) & Coarse microaggregate $(0.053-0.25 \mathrm{~mm})$ & 'Silt + clay' $(<0.053 \mathrm{~mm})$ \\
\hline & \multicolumn{4}{|l|}{$\mathrm{g} \mathrm{C} \mathrm{kg}^{-1}$ soil } \\
\hline \multicolumn{5}{|l|}{$0-0.05 \mathrm{~m}$} \\
\hline $\mathrm{CT}$ & $0.30 \mathrm{bC}^{1}$ & $5.70 \mathrm{bA}$ & $1.38 \mathrm{aB}$ & $0.96 b B$ \\
\hline NTS & $1.74 \mathrm{aB}$ & 7.36aA & $1.77 \mathrm{aB}$ & $2.07 a B$ \\
\hline NTM & $1.31 \mathrm{aB}$ & $6.90 \mathrm{aA}$ & $1.85 \mathrm{aB}$ & 1.67abB \\
\hline $\mathrm{LSD}_{0.05}$ & 0.57 & 0.58 & NS & 0.62 \\
\hline \multicolumn{5}{|l|}{$0.05-0.10 \mathrm{~m}$} \\
\hline $\mathrm{CT}$ & $0.46 \mathrm{bD}$ & $4.79 \mathrm{bA}$ & $1.18 \mathrm{aB}$ & $0.88 \mathrm{cC}$ \\
\hline NTS & $0.84 \mathrm{aC}$ & $5.84 \mathrm{aA}$ & $2.00 \mathrm{aB}$ & $1.55 \mathrm{aBC}$ \\
\hline NTM & $0.69 \mathrm{abC}$ & $4.5 \mathrm{bA}$ & $1.57 \mathrm{aB}$ & $1.22 \mathrm{bcBC}$ \\
\hline $\mathrm{LSD}_{0.05}$ & 0.29 & 0.59 & NS & 0.36 \\
\hline \multicolumn{5}{|l|}{$0.10-0.20 \mathrm{~m}$} \\
\hline $\mathrm{CT}$ & $0.24 \mathrm{bD}$ & 3.76aA & $1.84 \mathrm{aB}$ & $1.07 \mathrm{aC}$ \\
\hline NTS & $0.47 \mathrm{aC}$ & $3.35 \mathrm{aA}$ & $1.98 \mathrm{aB}$ & $0.88 \mathrm{aC}$ \\
\hline NTM & $0.43 a b c$ & $2.19 \mathrm{bA}$ & 1.66aB & $1.29 \mathrm{aB}$ \\
\hline $\mathrm{LSD}_{0.05}$ & 0.16 & 0.62 & NS & NS \\
\hline \multicolumn{5}{|l|}{$0.20-0.40 \mathrm{~m}$} \\
\hline $\mathrm{CT}$ & $0.1 \mathrm{aC}$ & 3.67aA & $0.87 \mathrm{bB}$ & $0.81 \mathrm{aB}$ \\
\hline NTS & $0.11 \mathrm{aC}$ & 2.19abA & $1.23 \mathrm{aB}$ & $1.01 \mathrm{aB}$ \\
\hline NTM & $0.18 \mathrm{aD}$ & 3.03aA & $1.38 \mathrm{aB}$ & $0.85 \mathrm{aC}$ \\
\hline $\mathrm{LSD}_{0.05}$ & NS & 0.82 & NS & NS \\
\hline \multicolumn{5}{|l|}{$0.40-0.60 \mathrm{~m}$} \\
\hline $\mathrm{CT}$ & $0.06 \mathrm{aC}$ & $2.44 \mathrm{aA}$ & $0.77 \mathrm{aB}$ & $0.58 \mathrm{aB}$ \\
\hline NTS & $0.05 \mathrm{aC}$ & 1.59abA & $0.74 \mathrm{aB}$ & $0.57 \mathrm{aB}$ \\
\hline NTM & $0.04 \mathrm{aC}$ & $1.07 \mathrm{bA}$ & $1.13 a A$ & $0.85 a B$ \\
\hline $\operatorname{LSD}_{0.05}$ & NS & 1.1 & NS & NS \\
\hline
\end{tabular}

CT: conventional tillage; NTS: no-tillage with residue cover; NTM: no-tillage with residue removed and manure applied.

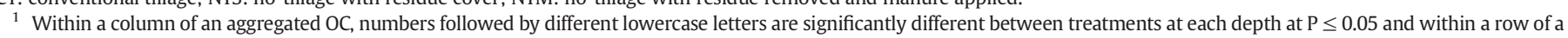
treatment, numbers followed by different uppercase letters are significantly different between different size classes at each depth at P $\leq 0.05$ by LSD test. 


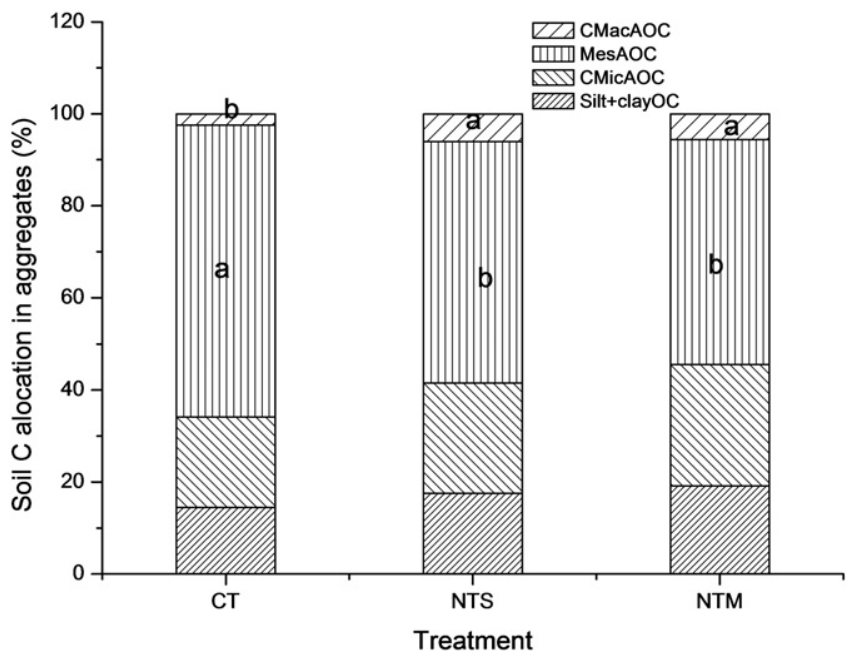

Fig. 1. Allocation of organic $\mathrm{C}$ in different aggregate size classes under different treatments at $0-60 \mathrm{~cm}$ depth: $\mathrm{CMaCAOC}=$ coarse macroaggregated $\mathrm{OC}(>2 \mathrm{~mm})$; MesAOC $=$ mesoaggregated $\mathrm{OC}(0.25-2 \mathrm{~mm})$; $\mathrm{CMiCAOC}=$ coarse microaggregated $\mathrm{OC}(0.05-$ $0.25 \mathrm{~mm})$; silt + clay OC $=$ "silt + clay" associated OC $(<0.053 \mathrm{~mm})$; Bars followed by different lowercase letters are significantly different between treatments at $\mathrm{P} \leq 0.05$ by LSD test. CT: conventional tillage; NTS: no-tillage with residue cover; NTM: no-tillage with residue removed and manure applied.

Within each aggregate size class, the aggregate-associated OC concentrations with coarse macroaggregates in the $0-20 \mathrm{~cm}$ soil layers and 'silt + clay' aggregates in the $0-10 \mathrm{~cm}$ soil layers were found to be greater under NTS and NTM treatments compared with CT. The OC concentrations within the mesoaggregate fraction under NTS treatment at $0-10 \mathrm{~cm}$ and under NTM treatment at $0-5 \mathrm{~cm}$ layer were significantly higher than those measured under CT. CT treatment was also found to result in higher mesoaggregate-associated $O C$ concentrations in the 10-60 cm soil layers compared with NTM, and the difference between CT and NTS treatments in 10-60 cm was not significant. There was also no significant difference in microaggregated organic carbon concentrations between treatments throughout the soil profile (Table 6).

The physical fractions of the four different aggregated $\mathrm{C}$ pools were distributed in MacAOC and MicAOC by 60 and 40\%, respectively (Fig. 1). Soil under CT contained a higher amount of MacAOC (66\%) compared with NTS-treated (59\%) and NTM-treated (54\%) soils, respectively, while lower values of MicAOC (34\% vs. 42 and 46\%, respectively) were measured. On average, the CMacAOC and MesAOC pools contained 8 and $92 \%$ of the total MacAOC, while CMicAOC and 'silt + clay' OC accounted for 58 and $42 \%$ of the total MicAOC, respectively. CT treatment resulted in greater MesAOC (63\%) compared with the NTS (52\%) and NTM (49\%) treatments. In addition, the aggregated C $(<2.0 \mathrm{~mm})$ was found to account for 98,94 and $94 \%$ of the total aggregated OC for the CT, NTS and NTM treatments, respectively. The aggregated $\mathrm{C}(<2.0 \mathrm{~mm})$ was found to be distributed among MesAOC, CMicAOC and 'silt + clay' OC at a ratio of $3.2: 1.4: 1$ and contributed 58,24 and $18 \%$, respectively.

\section{Discussion}

Generally, under NT systems, the upper soil tended to display increased $\mathrm{BD}$ due to greater compaction when compared with $\mathrm{CT}$. Bhattacharyya et al. (2009) found that NT increased the BD, MWD and the proportion of macroaggregate fractions $(>0.25 \mathrm{~mm})$ in soil compared with $\mathrm{CT}$ in the surface layer of soil. In contrast, a decline in $\mathrm{BD}$ in the $0-20 \mathrm{~cm}$ layer in the NTS- and NTM-treated plots relative to the CT-treated plots was observed in the present study. Similar compaction occurred during sowing and harvesting under CT, NTS and NTM systems in our long-term experiments. The decrease in BD was not significant under NTS and NTM treatments compared with CT, which may be partially attributed to the increase in SOC content resulting from application of crop residue (NTS) or manure (NTM) (Table 4). SOC likely directly impacted the $\mathrm{BD}$, as the particle density of organic matter is considerably lower than that of mineral soil (Pikul and Zuzel, 1994; Franzluebbers, 2010). Arvidsson (1998) reported a lower BD in soils with higher levels of organic matter. A decrease in BD in the $0-10 \mathrm{~cm}$ layer under NT treatment with higher crop-residue levels was also observed by Blanco-Canqui and Lai (2007) and Ghuman and Sur (2001).

In contrast to the decreasing trend observed with $\mathrm{BD}$, soil infiltration parameters $\left(A, i_{i}, i_{c}\right.$, and $\left.I\right)$ were observed to increase at surface soil under NTS and NTM compared with CT. This finding is consistent with results from previous studies (Franzluebbers, 2002; Shukla et al., 2003; Alvarez and Steinbach, 2009). Since organic materials have relatively low bulk density and higher porosity, the addition of organic matter to soil through application of crop residues (NTS) or manure (NTM) generally results in a decline in $\mathrm{BD}$ (Celik et al., 2004). As a result of soil biological activity under NTS and NTM systems, increased aggregation and permanent pore development resulted in an increase in the amount of macro-aggregates and the total and effective porosity. This in turn led to greater infiltration and crop water availability (McVay, 2006). The lower infiltration rates observed under CT may be also associated with the additional compaction in the sub-soil during seedbed preparation. However, the greater $i_{c}$ observed under NTS and NTM compared with CT may also be attributed to the production and preservation of channels by earthworms and plant roots (Strudley et al., 2008).

The surface application of crop residues and manure likely isolated the residue and raw material from the soil profile under NTS and NTM treatments, which impacted the percentage of macroaggregates $(>0.25 \mathrm{~mm})$ and SOC concentration in surface soil layer compared with CT. Prior studies have also reported a higher SOC concentration near the surface layer in NT compared with CT soils (Hernanz et al., 2009; Sombrero and de Benito, 2010). The higher input of crop residues and raw material in the NT system is known to play a key role in aggregation of the soil (Barreto et al., 2009; Álvaro-Fuentes et al., 2009). Live roots or organic material and decomposing roots have been reported to release compounds rich in carbon which can serve as energy sources for soil microbiota (Six et al., 2006). These organisms in turn are capable of releasing considerable quantities of polysaccharides, which also contribute to soil aggregation. Consequently, SOC which accumulated in the top soil layer was occluded by soil macroaggregates (Six et al., 1999; Hernanz et al., 2002). Conversely, the low concentrations of carbon at the surface under CT treatments can likely be attributed to dilution of organic matter during tillage and also to rapid mineralization resulting from high oxidation rates and greater microbial activity (Dolan et al., 2006; Balesdent et al., 2000). The greater accumulation of SOC in the bottom layer under CT treatment may result from the transfer of crop residues into the subsoil and from crop root growth and distribution in deeper soil layer (Stemmer et al., 1999). Prior field observations have indicated that crop roots under CT systems were relatively denser and larger compared with roots under NT systems in the bottom layers in the North China Plain (Zhang and Miao, 2006; Qi et al., 2012).

Although the percentages of aggregates $>2.0 \mathrm{~mm}$ were greater under NTS and NTM treatments compared to CT in 0-20 cm soil layer, the percentages of $0.25-2 \mathrm{~mm}$ under $\mathrm{CT}$ in all soil layers were significantly greater compared with NTS and NTM (48.4-62.8\% vs. 39.1$50.6 \%$ and $30.2-51.1 \%$ ) at all the soil depths. Higher concentrations of $\mathrm{C}$ in the coarse macroaggregates, mesoaggregates and 'silt + clay' fractions at soil surface were observed under NT systems compared with CT. However, at the 40-60 cm depth, greater mesoaggregated C concentrations in CT compared with NTS and NTM were measured. These results are in agreement with those from a study by Plaza-Bonilla et al. (2010). When mixing crop residues at depth (full inversion tillage case), residue $\mathrm{C}$ is moved in close proximity to mineral soil particles (Angers and 
Eriksen-Hamel, 2007). Stemmer et al. (1999) compared the distribution of corn-derived organic matter between different residue locations and concluded that organic matter is afforded better protection within inorganic compounds when mixed into the soil than when left on the soil surface. As a result, the same study also found that a greater fraction of SOC was transferred into the stable SOC pool in tilled soil compared with untilled soil. In the present study, while NTS and NTM systems were found to improve soil aggregate stability in only the $0-20 \mathrm{~cm}$ surface layer, the CT system improved stability throughout the soil profile. WSA $>0.25 \mathrm{~mm}$ (\%) was found to be greater than $50 \%$ and AR ranged from 1.26 to 2.16 , which may have a positive effect on soil water infiltration capacity in deep soil layers. However, the mechanisms controlling $C$ stabilization and the influence of $C$ on soil hydrology deep in the soil profile still require further investigation (Angers and EriksenHamel, 2007).

De Sanctis et al. (2012) reported that the accumulation of SOC under NT was also associated with the weed cover production during intercropping. However, different results were observed in the YRD under double crop rotation due to the herbicide application after sowing of wheat in October and maize in June. The estimated $C$ inputs from aboveground residual were determined to be $1.0( \pm 0.07)$ $\mathrm{Mg} \mathrm{ha}^{-1} \mathrm{yr}^{-1}$ for the current CT system (incorporated into soil profile), while $4.6 \mathrm{Mg} \mathrm{C} \mathrm{ha-1} \mathrm{yr}^{-1}$ from crop straws under NTS and 1.6 $\mathrm{Mg} \mathrm{C} \mathrm{ha}^{-1} \mathrm{yr}^{-1}$ from cattle manure under NTM remained on the soil surface. While CT was found to receive less $\mathrm{C}$ input aboveground compared with NTS and NTM, no difference in SOC content overall was observed in the $0-60 \mathrm{~cm}$ soil profile among treatments. Angers et al. (1993) reported a similar total SOC content in soils to a depth of $60 \mathrm{~cm}$ after 10 years of conservation tillage at eight sites and attributed these results to increased levels near the surface and lower values in the deeper layers. Although NT usually leads to the accumulation of SOC in the surface soil layers, this effect can be partially or entirely offset by the greater SOC stock near the bottom of the plow layer under CT treatments (West, and Post., 2002). This can be further attributed to the lower effectiveness of aboveground biomass to SOC sequestration even being incorporated into soil. In general, more of the root-derived $\mathrm{C}$ remains in soil than that of residue-derived C (52\% vs. 4\%) (Kong and Six, 2010). Greater root density was observed near the soil surface under NT compared with CT and an opposite trend was observed in the subsoil (Ball-Coelho et al., 1998; de Rouw et al., 2010; Wang et al., 2003). Within the soil profile, the root length density (RLD) was found to be significantly higher under NT than under CT at a depth of $5 \mathrm{~cm}$, whereas it was higher under CT than under NT below $10 \mathrm{~cm}$. Below $50 \mathrm{~cm}$, no difference was observed in RLD between the tillage systems (Qin et al., 2006). In Quzhou, China, the root amount of wheat in the deep tillage (CT) was found to be $76.6 \%$ higher than that in shallow tillage (10-12 cm depth), while the root biomass in $15-100 \mathrm{~cm}$ profile in this field was 1.22 times higher than that in shallow tillage (Lei et al., 2011). Baker et al. (2007) found that the differences in the distribution of wheat and maize roots between the NT and CT systems could result in different SOC distributions with depth. However, lack of data regarding crop roots hampers accurate interpretation of SOC profiles in the present study. Further investigations into crop root development and distribution under the three tillage systems in the studied area should be considered in future work.

Results in the present study also showed that a small amount of dry manure (3.46 $\mathrm{Mg} \mathrm{ha}^{-1} \mathrm{yr}^{-1}$ ) can potentially replace crop straw inputs (wheat straw $5.9 \mathrm{Mg} \mathrm{ha}^{-1}$ of wheat straw plus $4.9 \mathrm{Mg} \mathrm{ha}^{-1} \mathrm{yr}^{-1}$ of maize straw) to compensate for the $\mathrm{C}$ of 4.6 $\mathrm{Mg} \mathrm{ha}^{-1} \mathrm{yr}^{-1}$ due to residue removal. In the $20-60 \mathrm{~cm}$ layers, no significant difference was observed in SOC content between the NTM and CT treatments. The higher OC contents of soil at 20$60 \mathrm{~cm}$ in plots treated with NTM may be attributed to leaching and accumulation of soluble organic carbon from the manure. The addition of manure may have promoted microbial activities and the production of soluble carbon (Huang et al., 2011).

\section{Conclusion}

NTS and NTM treatments in the YRD were shown no promote soil water infiltration in the surface soil. NTS- and NTM-treated plots were also found to accumulate the highest amounts of SOC near the soil surface, which was accompanied by both higher macroaggregate content and higher macroaggregate $C$ concentrations. SOC sequestration in the 0-60 cm layers was not observed to be significantly different between treatments. SOC in 40-60 cm soil layers for CT plots and $20-40 \mathrm{~cm}$ layers for NTM plots was higher compared with that measured under NTS. Compared with NTS and NTM, CT treatment promoted both the proportion of the mesoaggregate $(0.25-2 \mathrm{~mm})$ fraction and the associated $C$ concentration throughout the soil profile. These results demonstrated that the use of organic matter inputs (crop straw or manure) together with a reduced urea rate under NT did not significantly increase SOC under the winter wheat/maize double cropping system in the YRD.

The findings indicate that a combination of NT with organic fertilizer may act to increase macroaggregate formation and improve soil physical properties at the soil surface. These impacts can be attributed to decreased soil disturbance and the addition of crop residues or manure. The positive effects of CT on SOC in deeper soil were attributed to crop root development in deeper soil layers. Future work should include observation of crop root distribution in the deeper soil profile and an evaluation of SOC dynamics in different tillage systems under the wheat-maize cropping system in the YRD.

\section{Acknowledgments}

This study was sponsored by the National Key Project for Basic Research (No. 2012CB417004) and the National Natural Scientific Foundation of China (Nos. 40471110, 41171390, and 41401591). We also thank two anonymous reviewers for their constructive comments, which helped improve the manuscript.

\section{References}

Abiven, S., Menasseri, S., Chenu, C., 2009. The effects of organic inputs over time on soil aggregate stability - a literature analysis. Soil Biol. Biochem. 41, 1-12.

Alvarez, R., Steinbach, H.S., 2009. A review of the effects of tillage systems on some soil physical properties, water content, nitrate availability and crops yield in the Argentine Pampas. Soil Tillage Res. 104, 1-15.

Álvaro-Fuentes, J., Cantero-Martínez, C., López, M.V., Paustian, K., Denef, K., Stewart, C.E., Arrúe, J.L., 2009. Soil aggregation and soil organic carbon stabilization: effects of management in semiarid Mediterranean agroecosystems. Soil Sci. Soc. Am. J. 73, 1519-1529.

Angers, D.A., N'dayegamiye, A., Côté, D., 1993. Tillage-induced differences in organic matter of particle-size fractions and microbial biomass. Soil Sci. Soc. Am. J. 57, 512-516.

Angers, D.A., Eriksen-Hamel, N.S., 2007. Full-Inversion tillage and organic carbon distribution in soil profiles: A meta-analysis. Soil Sci. Soc. Am. J. 72, 1370-1374.

Arvidsson, J., 1998. Influence of soil texture and organic matter content on bulk density, air content, compression index and crop yield in field and laboratory compression experiments. Soil Tillage Res. 49, 159-170.

Baker, J.M., Ochsner, T.E., Venterea, R.T., Griffis, T.J., 2007. Tillage and soil carbon sequestration - what do we really know? Agric. Ecosyst. Environ. 118, 1-5.

Balesdent, J., Chenu, C., Balabane, M., 2000. Relatioship of soil organic matter dynamics to physical protection and tillage. Soil Tillage Res. 53, 215-230.

Ball-Coelho, B.R., Roy, R.C., Swanton, C.J., 1998. Tillage alters corn root distribution in coarse-textured soil. Soil Tillage Res. 45, 249-273.

Barreto, R.C., Maddock, J.E.L., Machado, P.L.O.A., Torres, E., Franchini, J., Costa, A.R., 2009. The impact of soil management on aggregation, crbon stabilization and carbon loss as $\mathrm{CO}_{2}$ in the surface layer of a Rhodic Ferralsol in Southern Brazil. Agric. Ecosyst. Environ. 132, 243-251.

Benbi, D.K., Chand, M., 2007. Quantifying the effect of soil organic matter on indigenous soil N supply and wheat productivity in semi-arid sub-tropical India. Nutr. Cycl. Agroecosyst. 79, 103-112

Bhattacharyya, R., Prakash, V., Kundu, S., Srivastva, A.K., Gupta, H.S., 2009. Soil aggregation and organic matter in a sandy clay loam soil of the Indian Himalayas under different tillage and crop regimes. Agric. Ecosyst. Environ. 132, 126-134.

Blake, G.R. Hartge, K.H., 1986. Bulk density. In: Klute, A. (Ed.), Methods of Soil Analysis. Part 1, 2nd ed. . Agron. Monogr. 9. ASA and SSSA, Madison, WI, pp. 363-374.

Blanco-Canqui, H., Lai, R., 2007. No-tillage and soil profile carbon sequestration: an onfarm assessment. Soil Sci. Soc. Am. J. 141, 355-362. 
Buyanovsky, G.A., Wagner, G.H., 1998. Carbon cycling in cultivated land and its global significance. Glob. Chang. Biol. 4, 131-141.

Carter, M.R., 2004. Soil quality for sustainable land management: organic matter and aggregation interactions that maintain soil functions. Agron. J. 94, 38-47.

Cavalieri, K.M.V., Silva, A.P.D., Tormena, C.A., Leāo, T.P., Dexter, A.R., Hakansson, L., 2009. Long-term effects of no-tillage on dynamic soil physical properties in a Rhodic Ferralsol in Paraná, Brazil. Soil Tillage Res. 103, 158-164.

Celik, I., Ortas, I., Kilic, S., 2004. Effects of compost, mycorrhiza, manure and fertilizer on some physical properties of a Chromoxerert soil. Soil Tillage Res. 78, 59-67.

Dai, X.Q., Li, Y.S., Ouyang, Z., 2009. Investigation on area of winter wheat under no-tillage system in the north China Plain. Tillage Crop. 1, 53-54 (in Chinese).

de Rouw, A., Huon, S., Soulileuth, B., Jouquet, P., Pierret, A., Ribolzi, O., Valentin, C., Bourdon, E., Chantharath, B., 2010. Possibilities of carbon and nitrogen sequestration under conventional tillage and no-till cover crop farming (Mekong valley, Laos). Agric. Ecosyst. Environ. 136, 148-161.

De Sanctis, G., Paolo Roggero, P., Seddaiu, G., Orsini, R., Porter, C.H., Jones, J.W., 2012. Longterm no tillage increased soil organic carbon content of rain-fed cereal systems in a Mediterranean area. Eur. J. Agron. 40, 18-27.

Dolan, M.S., Clapp, C.E., Allmaras, R.R., Baker, J.M., Molina, J.A.E., 2006. Soil organic carbon and nitrogen in a Minnesota soil as related to tillage residue and nitrogen management. Soil Tillage Res. 89, 221-231.

Elliott, E.T., Cambardella, C.A., 1991. Physical separation of soil organic matter. Agric. Ecosyst. Environ. 34, 407-419.

Fliebbach, A., Oberholzer, H.-R., Gunst, L., Mader, P., 2007. Soil organic matter and biological soil quality indicators after 21 years of organic and conventional farming. Agric. Ecosyst. Environ. 118, 273-284

Franzluebbers, A.J., 2002. Water infiltration and soil structure related to organic matter and its stratification with depth. Soil Tillage Res. 66, 197-205.

Franzluebbers, A.J., 2010. Depth distribution of soil organic carbon as a signature of soil quality. 2010 19th World Congress of Soil Science, Soil Solutions for a Changing World. 1-6 August 2010, Brisbane, Australia (In: http://www.iuss.org/19th\% 20WCSS/Symposium/pdf/2164.pdf).

Ghuman, B.S., Sur, H.S., 2001. Tillage and residue management effects on soil properties and yields of rainfed maize and wheat in a subhumid subtropical climate. Soil Tillage Res. 58, 1-10.

Goddard, T., Zoebisch, M., Gan, Y., Ellis, W., Watson, A., Sombatpanit, S., 2008. No-till farming systems. World Association os Soil and Water Conservation (WASWC), Special, Publication No 3.

Gregorich, E.G., Drury, C.F., Baldock, J.A., 2001. Changes in soil carbon under long term maize in monoculture and legume-based rotation. Can. J. Soil Sci. 81, 21-31.

Guo, J.P., Zhou, C.D., 2007. Greenhouse gas emissions and mitigation measures in Chinese agroecosystems. Agric. For. Meteorol. 142, 270-277.

Haile, S.G., Nair, P.K.R., Nair, V.D., 2008. Carbon storage of different soil-size fractions in Florida silvopastoral systems. J. Environ. Qual. 37, 1789-1797.

Hernanz, J.L., Lopez, R., Navarrete, L., Sanchez-Giron, V., 2002. Long-term effects of tillage systems and rotations on soil structural stability and organic carbon stratification in semi-arid central Spain. Soil Tillage Res. 66, 129-141.

Hernanz, J.L., Sanchez-Giron, V., Navarrete, L., 2009. Soil carbon sequestration and stratification in a cereal/leguminous crop rotation with three tillage systems in semiarid conditions. Agric. Ecosyst. Environ. 133, 114-122.

Huang, S., Zhang, W.J., Yu, X.C., Huang, Q.R., 2010. Effects of long-term fertilization on corn productivity and its sustainability in an Ultisol of southern China. Agric. Ecosyst. Environ. 138, 44-50.

Huang, M.X., Liang, T., Ouyang, Z., Wang, L.Q., Zhang, C.S., Zhou, C.H., 2011. Leaching losses of nitrate nitrogen and dissolved organic nitrogen from a yearly two crops system, wheat-maize, under monsoon situations. Nutr. Cycl. Agroecosyst. 91, 77-89.

Huang, M., Liang, T., Wang, L., 2015. Nitrous oxide emissions in a winter wheat-summer maize double cropping system under different tillage and fertilizer management. Soil Use Manag. http://onlinelibrary.wiley.com/doi/10.1111/sum.12170/pdf.

Jastrow, J.D., Miller, R.M., 1991. Methods of assessing the effects of the biota on soil structure. Agric. Ecosyst. Environ. 34, 279-303.

Karami, A., Homaee, M., Afzalinia, S., Ruhipour, H., Basirat, S., 2012. Organic resource management: impacts on soil aggregate stability and other soil physic-chemical properties. Agric. Ecosyst. Environ. 148, 22-28.

Kong, A.Y.Y., Six, J., 2010. Tracing root vs. residue carbon into soils from conventional and alternative cropping systems. Soil Sci. Soc. Am. J. 74, 1201-1210.

Kou, T.J., Zhu, P., Huang, S., Peng, X.X., Song, Z.W., Deng, A.X., Gao, H.J., Peng, C., Zhang, W.J., 2012. Effects of long-term cropping regimes on soil carbon sequestration and aggregate composition in rainfed farmland of Northeast China. Soil Tillage Res. 118, 132-138.

Lal, R., 2004. Soil carbon sequestration to mitigate change. Geoderma 123, 1-22.

Lal, R., Kimble, J.M., Follett, R.F., Cole, C.V., 1998. The potential of US cropland to sequester carbon and mitigate the greenhouse effect. Ann Arbor Press, Chelsea, MI 128pp.

Lei, Y., Cai, G.X., Niu, X.S., Zhang, H.Y., 2011. Influence of deep tillage on distribution of wheat root system in soil profile. Acta Agron. Sin. 8, 271-275.

Liu, X.J., Ju, X.T., Zhang, F.S., Pan, J.R., Peter, Christie, 2003. Nitrogen dynamics and budgets in a winter wheat-maize cropping system in the North China Plain. Field Crops Res. 83, 111-124.
McVay, K.A., 2006. Soil Physical Conditions in Conservation Tillage Systems. Kansas State Univ.-Research and Extensions (In: www.agecon.Okstate.edu/isct/labranza/mcvay/ soilphys.doc).

Mkhabela, M.S., Madani, A., Gordon, R., Burton, D., Cudmore, D., 2008. Gaseous and leaching nitrogen losses from no-tillage and conventional tillage systems following surface application of cattle manure. Soil Till. Res. 98, 187-199.

Nelson, D.W., Somers, L.E., 1982. Total carbon, organic carbon, and organic matter. In Page, A.L., Miller, R.H., Keeeney, D.R. (Eds.), Methods of Soil Analysis. Part 2. Chemical and Microbiological Properties. Agronomy Society of America and Soil Science Society of America, Madison, WI, pp. 539-580.

Obalum, S.W., Obi, M.E., 2010. Physical properties of a sandy loam Ultisol as affected by tillage-mulch management practices and cropping systems. Soil Tillage Res. 108, 30-36.

Oguike, P.C., Mbagwu, J.S.C., 2009. Variations in some physical properties and organic matter content of soils of coastal plain sand under different land use types. World J. Agric. Sci. 5 (1), 63-69.

Pastorelli, R., Vignozzi, N., Landi, S., Piccolo, R., Orsini, R., Seddaiu, G., Roggero, P.P., Pagliai, M., 2013. Consequences on macroporosity and bacterial diversity of adopting a notillage farming system in a clayish soil of Central Italy. Soil Biol. Biochem. 66, 78-93.

Pathak, H., Byjesh, K., Chakrabarti, B., Aggarwal, P.K., 2011. Potential and cost of carbon sequestration in Indian agriculture: estimates from long-term field experiments. Field Crops Res. 120, 102-111.

Philip, J.R., 1957. The theory of infiltration. 4. Sorptivity and infiltration equations. Soil Sci. 84, 257-264.

Pikul Jr., J.L., Zuzel, J.F., 1994. Soil crusting and water infiltration affected by long-term tillage and residue management. Soil Sci. Soc. Am. J. 58 (5), 1524-1530.

Plaza-Bonilla, D., Cantero-Martínez, C., Álvaro-Fuentes, J., 2010. Tillage effects on soil aggregation and soil organic carbon profile distribution under Mediterranean semiarid conditions. Soil Use Manag. 26, 465-474.

Qi, W.Z., Liu, H.H., Li, G., Shao, L.J., Wang, F.F., Liu, P., Dong, S.T., Zhang, J.W., Zhao, B.P. 2012. Temporal and spatial distribution characteristics of super-high-yield summer maize root. Plant Nutr. Fertil. Sci. 18 (1), 69-76.

Qin, R.J., Stamp, P., Richner, W., 2006. Impact of tillage on maize rooting in a Cambisol and Luvisol in Switzerland. Soil Tillage Res. 85, 50-61.

Robertson, G.P., Paul, E.A., Harwood, R.R., 2000. Greenhouse gases in intensive agriculture: contributions of individual gases to the radiative forcing of the atmosphere. Science 289, 1922-1925.

Shukla, M.K., Lai, R., Ebinger, M., 2003. Tillage effects on physical and hydrological properties of a typic Argiaquoll in central Ohio. Soil Sci. 168, 802-811.

Shukla, M.K., Lai, R., Ebinger, M., 2006. Determining soil quality indicators by factor analysis. Soil Tillage Res. 87, 194-204.

Six, J., Elliott, E.T., Paustian, K., 1999. Aggregate and soil organic matter dynamics under conventional and no-tillage systems. Soil Sci. Soc. Am. J. 63, 1350-1358.

Six, J., Contant, R.T., Paul, E.A., Paustian, K., 2002. Stabilization mechanisms of soil organic matter: implications for C-saturation of soils. Plant Soil 241, 155-176.

Six, J., Frey, S.D., Thiet, R.K., Batten, K.M., 2006. Bacterial and fungal contributions to C sequestrations in agroecosystems. Soil Sci. Soc. Am. J. 70, 555-569.

Sombrero, A., de Benito, A., 2010. Carbon accumulation in soil. Ten-year study of conservation tillage and crop rotation in a semi-arid area of Castile-Leon, Spain. Soil Tillage Res. 107, 64-70.

Stemmer, M., Lutzow, M., Kandeler, E., Pichlmayer, F., Gerzabek, M.H., 1999. The effect of maize straw placement on mineralization of $\mathrm{C}$ and $\mathrm{N}$ in soil particle size fractions. Eur. J. Soil Sci. 50, 73-85.

Strudley, M.W., Green, T.R., Ascough II, J.C., 2008. Tillage effects on soil hydraulic properties in space and time: state of the science. Soil Tillage Res. 99, 4-48.

Tejada, M., Garcia, C., Gonzalez, J.L., Hernandez, M.T., 2006. Organic amendment based on fresh and composted beet vinasse: influence on physical, chemical and biological properties and wheat yield. Soil Sci. Soc. Am. J. 70, 900-908.

Tisdall, J.M., Oades, J.M., 1982. Organic matter and water-stable aggregates in soils. J. Soil Sci. 33, 141-163.

Wagner, S., Cattle, S.R., Scholten, T., 2007. Soil-aggregate formation as influenced by clay content and organic-matter amendment. J. Plant Nutr. Soil Sci. 170, 173-180.

Wang, W.J., Dala, R.C., 2006. Carbon inventory for a cereal cropping system under contrasting tillage, nitrogen fertilization and stubble management practices. Soil Tillage Res. 91, 68-74.

Wang, F.H., Wang, X.Q., Ren, D.C., Yu, Z.E., Yu, S.L., 2003. Effect of soil deep tillage on root activity and vertical distribution. Acta Agric. Nucl. Sin. 17 (1), 56-61.

West, T.O., Post, W.M., 2002. Soil organic carbon sequestration rates by tillage and crop rotation: a global data analysis. Soil Sci. Soc. Am. J. 66, 1930-1946.

Wright, A.L., Hons, F.M., Matocha, J.E., 2005. Tillage impacts on microbial biomass and soil carbon and nitrogen dynamics of corn and cotton rotations. Appl. Soil Ecol. 29, 85-92

Yang, X.M., Drury, C.F., Reynolds, W.D., Tan, C.S., 2008. Impacts of long-term and recently imposed tillage practices on the vertical distribution of soil organic carbon. Soil Tillage Res. 100, 120-124.

Yu, G., Fang, H., Gao, L., Zhang, W., 2006. Soil organic carbon budget and fertility variation of black soils in Northeast China. Ecol. Res. 21, 855-867.

Zhang, Y.Q., Miao, G.Y., 2006. Biological response of winter wheat root system to fertilization depth. Chin. J. Eco-Agric. 14 (4), 72-75 (in Chinese). 